一位加算作業パフォーマンスによる被験者タイプの分類法及び 室内空気污染が異なる被験者群へ及ぼす影響に関する試験研究

\title{
PILOT STUDY ON THE CLASSIFICATION OF SUBJECTS BASED ON THE PERFORMANCE OF THE ADDITION TASK AND THE EFFECT OF INDOOR AIR POLLUTION ON DIFFERENT TYPES OF SUBJECTS
}

\author{
岩下 剛*, 合原妙 美** \\ Go IWASHITA and Taemi GOHARA
}

\begin{abstract}
Perceived air quality, Sick Building Syndrome (SBS) symptoms and productivity were studied in a test house at Kagoshima University. The air pollution level was modified by introducing or removing a pollution source of rubber-carpet. Eighteen college-aged subjects were exposed to the two rooms, one room (room A) with the pollution source present and the other room (room B) with the pollution source absent. The subjects assessed the perceived air quality, indoor climate and SBS symptoms upon entering the room and on several occasions during each exposure in the room. During each exposure of $\mathbf{4 0}$ minutes, the subjects performed serial one-figure addition task. The odor intensity and the throat dryness in room A were higher than those in room B. It was found that there was no significant difference in total score of serial one-figure addition task between two rooms. However significant difference in fatiguability was found between two rooms for the subjects whose performance curve was kept constant.
\end{abstract}

\section{Keywords: One-Figure Addition Task, Odor Intensity, Perceived Air Quality, Productivity} 一位加算作業、臭気強度、知覚空気質、作業効率

\section{1 はじめに}

室内環境が作業効率に及ぼす研究は、英国で 1919 年に行われた Vernon の研究以来、数多く行われている。Vernon は、6 年にわたり、

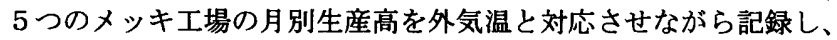
気温の上昇につれて生産高は低下寸ると結論した 1)。これら初期の 仕事場における心理学研究においては、環境刺激の効果は誰にも一 様であると考えており、人と環境との関係は「機械論的」かつ「決 定論的」であったと、Sundstrom らは述べている2)。

Vernon の研究の 5 年後、米国シカゴのホーソン工場において行わ れた「生産効率と照明に関する研究」では、明るさを変化させても、 生産率の変動に有意な影響は見られなかったという結果が得られた 3)。特に、明るさを弱めても生産高が減少することはなかった理由と して、被験者が実験者に観察されることによる動機付けの効果であ ろうと考えられ、この効果は「ホーソン効果」と呼ばれるようにな った。Sundstromは、人間の環境への応答には、いくつかの心理的過 程が含まれており、その心理的過程が人間の作業効率に影響を及ぼ すと述べている。彼が述べる心理的過程とは、覚醒、ストレス、注 意散漫、過負荷、疲労、順応である。同じ環境刺激が与えられれば、
同じ作業パフォーマンスが得られるという、機械論的な考え方では なく、心理的過程の差異により、得られる作業パフォーマンスは異 なるということである。

環境刺激と反応（パフォーマンス）だけを考慮した機械論的なモ デルが、心理学における行動主義と捉えることができるのに対し、 環境刺激と反応の間に人間側の心理的過程という媒介変数を仮定す るモデルは、環境刺激一生態一反応の関係に基づく新行動主義 4) に 対応すると考えられる。たとえば、各個人の作業に対するモチべー ションの違いによる作業パフォーマンスー及ぼす影響が、環境刺激 の影響よりも大きいことが考えられる。しかし、このような人間の 内的様相を把握することは容易ではなく、作業時の人間の心理的過 程・内的様相を評価する手法の開発が望まれる。

温熱、騒音、空気污染などの環境刺激が作業効率に及ぼす影響に 関する研究が国内外で行われており 5)、被験者に課す作業として、 パソコンを用いた校正作業、瞬時判別作業、文字入力作業などが用 いられている 6)、7)。日本においては、作業効率を計る指標として、 戦前から一位加算作業が多く用いられており、建筑分野における室 内環境評価研究では、実施時間内に被験者が計算した一位加算作業
* 鹿児島大学工学部建築学科 助教授・工博

** 鹿児島県立短期大学生活科学科 非常勤講師・家修
Assoc. Prof., Dept. of Architecture, Faculty of Engineering, Kagoshima University, Dr. Eng.

Lecturer, Dept. of Life and Environmental Science, Kagoshima Prefectural College, M. Home Eco. 
の計算量を、被験者のパフォーマンスとして捉えることが少なくな い。これは従来、心理学の分野で、内田・クレペリン精神作業検査と して開発されたものであり、実験結果より得られる作業曲線から、 人間の精神活動の様相をみようとするものである8 ${ }^{8}$ 。

室内環境評価の研究においても、「内田-クレペリン精神作業検査」 を行う場合のように、1 分あたりの一位加算作業計算量の経時推移 カーブ (作業曲線) を求め、その形状から被験者の内的様相を推測 することが可能と考えられる。そこで、ゴムカーペットから放たれ る空気污染物質によって污染された室内に被験者を曝露し、一位加 算作業を行わせ、得られたパフォーマンスの作業曲線の結果を用い て、被験者のタイプ分けが可能であるかの検討を試みた。また、室 内空気污染が、グループ分けされた異なる被験者群へ及ぼす影響を 考察した。

\section{2 .実験方法}

\section{1 実験箇所及び実験条件}

実験は鹿児島大学構内の実験住宅の室 A、室 Bにおいて行った。 実験室の平面図を図 1 に示す。実験住宅は室温の設定が可能であり、 また機械換気（各室 $15 \mathrm{~m}^{3} / \mathrm{h}$ ）がなされている。室内空気污染源とし て、室 $\mathrm{A}$ にのみ、市販されているスチレンブタジエンゴムカーペッ ト（大きさ $30 \mathrm{~cm} \times 30 \mathrm{~cm} ） 2$ 枚を敷設した。ただし、視覚による心 理的影響を除くために、部屋の一部を白い布で仕切り、仕切られた 他方の空間は被験者からは見えない状態として供試材を敷設した。 本実験で使用したゴムカーペットは、自動車内の中敷、階段の滑り 止め等に用いられるものであり、このゴムカーペットについては、 著者らの既往の研究において、供試材面積と発生量との関係を得て いる 9)。また、室内曝露の後、一定の初期時間が経過すると、発生 量の経時减衰の少ない材料と考えられるため、室内污染源の供試材 として選定した。室内の空気は扇風機を用いて器拌状態にした。な お、被験者は空気質の実験であることを知らされていなかった。各 室の空気温度は各室のヒーートポンプにより $25^{\circ} \mathrm{C}$ に設定した。被験者 として健康な大学生 18 名（男性 13 名、女性 5 名）が実験に参加し、 正当な報酬が支払われた。被験者は、化精品、香水などの臭いのす るものを身につけることを禁じられた。また、被験者は全員、実験 後にパネルスクリーニングテスト（3 基淮臭液使用）を受けたが、 嗅覚に異常があると判断された者はいなかった。

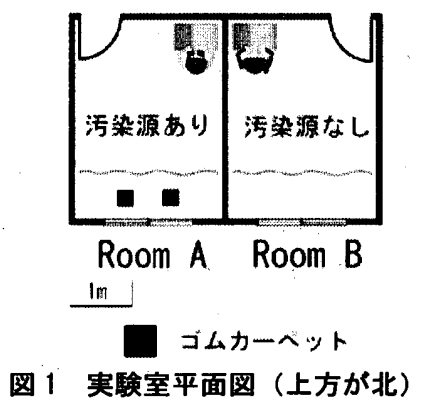

\section{2 アンケート項目}

表 1 に示す空気環境に関するアンケート、表 2 に示す形容詞対を 用いた SBS (シックビル症候群) アンケート及び作業時の努力度に
関するアンケートについて被験者から申告を得た。表 2 の質問項目 は Wargocki らの研究 ${ }^{6}$ で用いたものを筆者らが和訳し若干の修正を 加えたものである。なお、アンケート上の各評価尺度は、表 1 、表 2 に示したように数量化したが、実際の実験中に用いたアンケート用 紙には、この数值は揭載しなかった。

\section{3 測定項目}

空気温度、相対湿度は温度・湿度データロガー (Thermo Recorder TR-72S）により 10 分間隔で測定した。各室の空気は、サンプリン グポンプを用いてテナックス管に約 1 リットルの空気を通過させる ことによって VOC 成分を吸着させた後、ガスクロマトグラフ/質量 分析装置（以下 GC/MS と記す）で分析を行った。

表 1 空気環境に関するアンケート

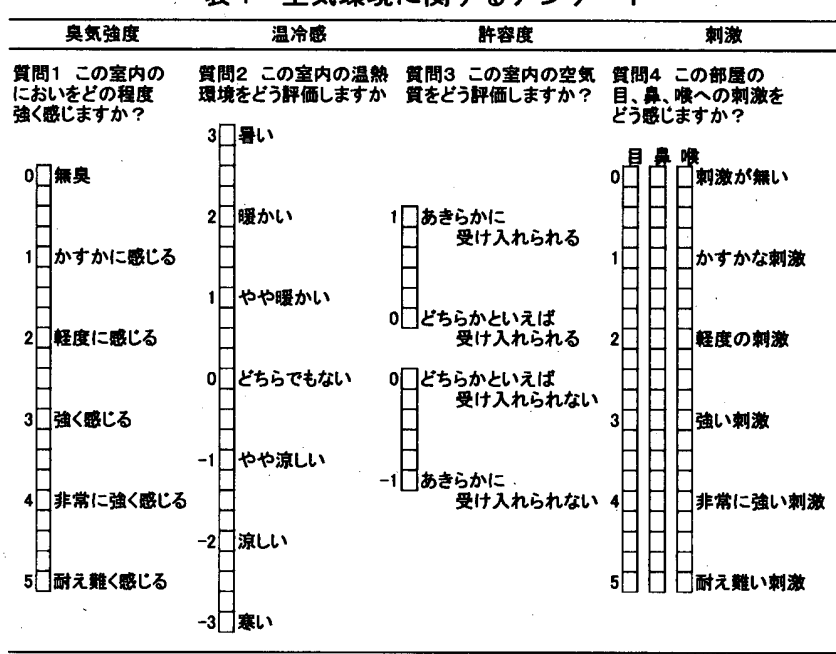

表 2 SBS 評価アンケート及び作業時の努力度に関するアンケート

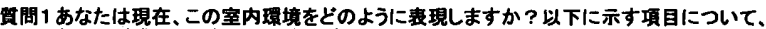
あなたが感しる程度に相当するボックスにチェックを入れて答えてください。

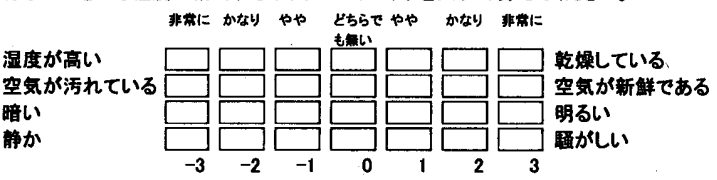

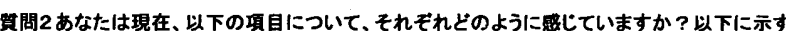
各項自について、あなたが感しる程度に相当するボックスにチェツクを入れてください。

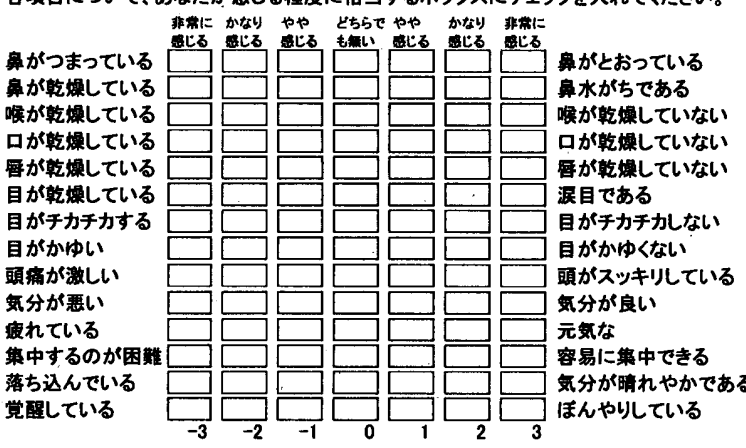

筫問3 あなたは、いま終了した計㫷作莱を遂行するにあたり、どの程度の能力を発揮できましたか 口自分の能力の100\%を哞揮できた 【自分の能力の $90 \%$ 程度を発揮できた

口自分の能力の80\%程度を哭揮できた 】自分の能力の70\%程度を発揮できた

口自分の能力の60\%程度を甡揮できた 口自分の能力の( )\%程度を発揮できた

○自分の能力をほとんど発揮てきなかった

\section{4 一位加算作業}

各室における被験者の作業効率を評価するために、作業として、 
内田・クレペリン精神作業検查で用いられる一位加算作業を用いた。 被験者は、ランダムに並べた数列の隣り合わせの数字の和の 1 位を 数字間のスペースに記入した。実験で使用した作業用紙では、1 行 は 90 個の数字からなり、作業開始後 1 分ごとの実験実施者の合図で 次の行に移り計算を続けた。正式な内田・クレペリン精神作業検査で は、この行換えは 15 回 (15 分) 行われ、5 分の休款後、再び 15 分 の繰り返し計算を行う(横田の場合 ${ }^{8}$ ) は、前半 15 分、 5 分休憩の後、 後半 10 分)。しかし、本実験では、二つの室に、それぞれ 40 分在室 し、入室 5 分後及び 25 分後に一位加算作業を実施することを計画し たため、疲労度も考慮し、1回の一位加算作業は 7 分 $(7$ 行) とし た。本実験では、臨床心理の分野において用いられる内田-クレペリ ン精神作業検査のように、各個人の作業曲線の異常傾向を検討する 精神分析が目的ではないことも、正式な設定時間を採用しなかった 理由の一つである。

\section{5 実験手順}

図 2 に実験スケジュールを示す。污染源であるゴムカーペットは 実験開始 165 分前に室 $\mathrm{A}$ に敷設した。被験者は室 $\mathrm{A}$ と室 $\mathrm{B}$ に 1 名ず つ入室し、40 分間座位状態で曝露された。室 $\mathrm{A}$ と室 $\mathrm{B}$ 一の入室順序 はランダムになるようにした。申告や一位加算作業は指示に従い図 2 下段に示す手順で行った。なお、被験者は実験前に、一位加算作 業にあらかじめ習熟しておくようにした。
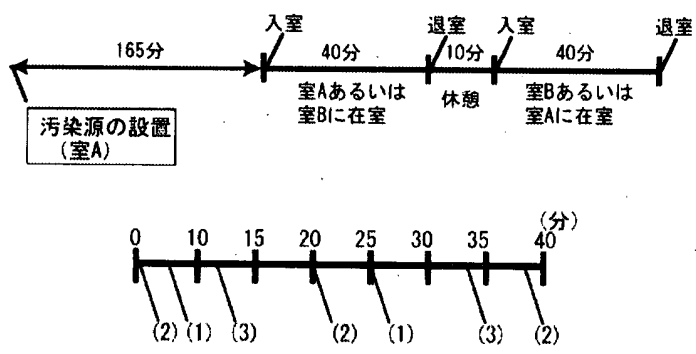

(1) 一位加算作業

(2) 空気䡒境アンケート

(3) SBSアンケート

図 2 実験スケジュール（上段 : 全体の流れ、

下段 : 各室における詳細スケジュール)

\section{3 実跧結果}

\section{1 物理量測定結果}

室 $\mathrm{A} 、$ 室 $\mathrm{B}$ の、空気温度は平均 $25.5^{\circ} \mathrm{C}$ 、相対湿度は平均 $52.5 \%$ 、 各室の換気量は $15 \mathrm{~m}^{3 / \mathrm{h}}$ であった。 GC/ MS 法による各条件のトル エン等価の TVOC 濃度は、各空空気のガククロマトグラムのピーク 面積の合計をトルエン換算することによって求めた。TVOC 濃度は 室 A が $418 \mu \mathrm{g} / \mathrm{m}^{3} 、$ 室 B が $284 \mu \mathrm{g} / \mathrm{m}^{3}$ と、污染源を敷設した室 $\mathrm{A}$ の濃度が室 $\mathrm{B} よ り$ 高い值となっている。室 $\mathrm{A}$ 及び室 $\mathrm{B}$ において、 それぞれ 2 回ずっ VOC 濃度測定を行った結果を表 3 に示す。表 3 中で VOC 名の後に印がついている物質は、標準試料が無いために、 トルエン等価で定量したものである。表 3 をみると、室 $\mathrm{A}$ と室 B で VOC 濃度に大きな差異は無く、ゴムカーペットから放たれる莫気の 主成分は明確にはできなかった。Sollinger らはスチレンブタジェン ゴムカーペットから放出される VOC の同定・定量を調査する実験 10)を行ない、26 の VOC の発生を確認している。その中に、 benzothiazole が含まれているが、本実験においても NIST ライブラ リーのマッチングによって、benzothiazole が室 Aにおいてのみ検出 されている。追加実験で、ゴムカーペットを敷く枚数を倍にしたと ころ、 benzothiazole 濃度は倍になったことから、この VOC はゴムカ 一ペットから放出された可能性が高い。本測定では、実大の居室少 イズで発生物質を調査したが、より高い精度を得るために、今後、 スモールチャンバー法を用いて、ゴムカーペットからの発生物質の 確認をする必要がある。

表 3 室 A 及び室 B におけるVOC 濃度 $\quad\left(\mu \mathrm{g} / \mathrm{m}^{3}\right)$

\begin{tabular}{|c|c|c|c|c|}
\hline & \multicolumn{2}{|c|}{ Room A } & \multicolumn{2}{|c|}{ Room B } \\
\hline VOC & 1 st & 2nd & 1 st & 2nd \\
\hline toluene & 18.65 & 19.76 & 18.88 & 18.05 \\
\hline ethylbenzene & 2.61 & 2.98 & 2.72 & 2.56 \\
\hline $\mathrm{p}, \mathrm{m}$-xylene & 2.29 & 2.52 & 2.54 & 2.20 \\
\hline styrene & 2.08 & 2.52 & 2.74 & 2.06 \\
\hline o-xylene & 2.53 & 3.03 & 2.91 & 2.66 \\
\hline $1,2,4-\mathrm{TMB}$ & 2.84 & 2.64 & 2.91 & 2.58 \\
\hline 1,4-dichlorobenzene & 0.34 & 0.21 & 0.37 & 0.24 \\
\hline decane & 1.44 & 1.52 & 1.77 & 1.35 \\
\hline limonene & 3.07 & 3.83 & 4.31 & 3.17 \\
\hline nonanal & 15.35 & 13.38 & 10.03 & 17.96 \\
\hline undecane & 0.80 & 0.69 & 0.74 & 0.69 \\
\hline decanal & 0.89 & 0.78 & 0.63 & 1.05 \\
\hline hexanal $^{*}$ & 8.84 & 10.20 & 11.97 & 8.55 \\
\hline 2-Ethylhexanol* & 16.93 & 9.80 & 13.32 & 10.26 \\
\hline benzothiazole* & 3.81 & 3.80 & nd & nd \\
\hline temperature $\left[{ }^{\circ} \mathrm{C}\right]$ & 25.2 & 25.6 & 25.3 & 25.5 \\
\hline relative humidity [\%] & 53.5 & 56.0 & 55.0 & 56.0 \\
\hline
\end{tabular}

\section{2 被験者の申告結果}

図 3 に被験者全員の平均値による臭気強度（表 1 の質問 1) の経 時変化を条件別に示す。プロットの上下のバーは標準偏差を示す。 申告值の数量化は表 1 に示したアンケート用紙中の数值を用いて行 った。経過時間は、被験者が各室に入室した時刻をぜロとしている。 $\mathrm{p}$ 值は、一対の標本による平均值の $\mathrm{t}$ 検定における、片側検定の有

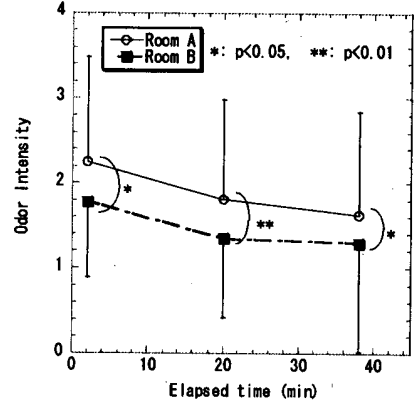

図 3 臭気強度の被験者全員の 平均値の経時変化

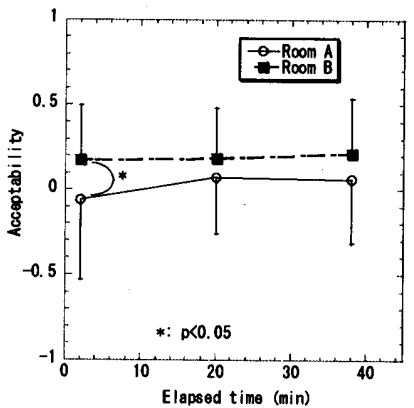

図 4 許容度の被験者全員の 平均値の経時変化
意水準を示す。 40 分の滞在時間中に 3 回行われた臭気強度申告にお いて、どの回においても、污染源を敷設した室 $\mathrm{A} の$ 臭気強度が室 $\mathrm{B}$ の臭気強度に比べ有意に高いという結果を得た $(\mathrm{p}<0.05)$ 。嗅覚疲労 を起こしていないと考えられる、入室時の平均臭気强度は、ゴム力 一ペットを敷いた室 A が 2.3、敷いていない室 B が・1.8 であった。 
経過時間とともに、平均臭気強度は低下していき、退室前の時点で は、室A は 1.6、室 B は 1.3 となっている。

図 4 に被験者全員の平均值による許容度（表 1 の質問 3) の経時 変化を示す。どの回の許容度申告においても、污染源を敷設した室 $\mathrm{A}$ の許容度が室 $\mathrm{B} に$ 比べ低かった。入室時の平均許容度は、ゴム力 ーペットを敷いた室 A が-0.06、敷いていない室 B が 0.18 であった。 入室時の平均許容度の值より、両室の知覚空気污染物質発生量 ${ }^{11}$ を 求めたところ、室 A が 3.1 olf、室 B が 1.2 olf であった。なお、知 覚空気污染度 11) は、室 $\mathrm{A}$ が 7.7 decipol、室 B が 3.0 decipol であう た。

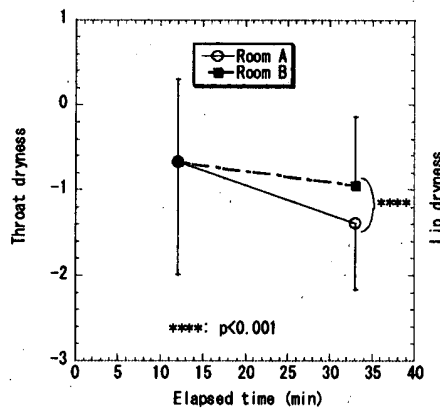

図 5 喉の乾嬠感の被験者 全員の平均值

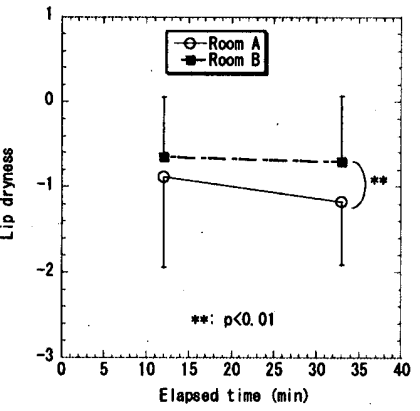

図 6 唇の乾嬠感の被験者 全員の平均値
図 5 に被験者全員の平均値による喉の乾燥感の経時変化を、図 6 に唇の乾燥感の経時変化を示す。乾燥感は、表 2 に示すアンケート の質問 2 中の「喉（もしくは唇）が乾燥している↔乾燥していない」 の形容詞対尺度において、「非常に乾燥している」に-3を、「非常に 乾燥していない」に+3 の数値を与えて数量化したものである。喉・ 唇の乾燥感は、污染源のある室 $\mathrm{A}$ において、滞在時間の経過ととも に乾燥感が增し、33 分後の申告では、室 $\mathrm{A}$ の乾燥感が、室 $\mathrm{B}$ より も有意に「乾燥している」側になっている $(\mathrm{p}<0.001[$ [㬋]、 $\mathrm{p}<0.01[$ 唇])。 実験室在室中、相対湿度に経時変動は無いため、被験者は、ゴムカ 一ペットによる空気污染を、乾燥感として知覚している可能性が考 えられる。室内空気污染が、相対湿度の変化が無いにも関わらず、 喉の乾燥感を生じさせた結果は、著者らが以前実施した研究の結果 12)、13) と一致している。

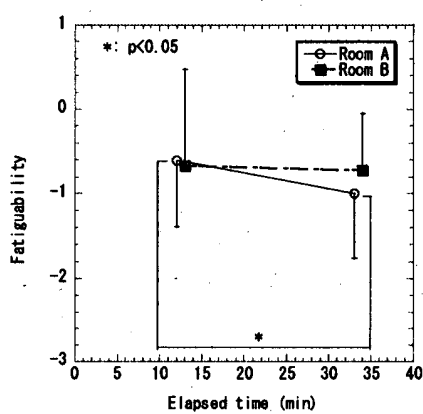

図 7 疲労感の被験者全員の 平均値の経時変化

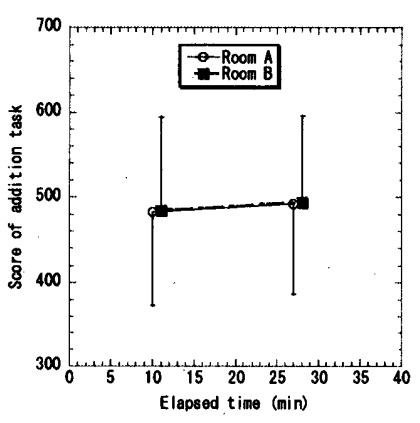

図 8 一位加算作業量の全被 験者平均値の経時変化
図 7 に、両室における自己申告による疲労感の全被鈤者平均値を 示す。疲労感とは、表 2 に示すアンケートの質問 2 中の「疲れてい
る↔元気な」の形容詞対尺度において、「非常に疲れている」に-3を、 「非常に元気な」に+3の数值を与えて数量化したものである。入室 33 分後に行われた 2 回目の申告では、ゴムカーペットを敷いた室 $\mathrm{A}$ において、室 Bより「疲れている側の申告となっているが、両室の 平均申告値間に $10 \%$ の有意水準では有意差がなかった（p<0.103）。 各室における申告值の時間推移をみると、室 $\mathrm{A}$ において、滞在時間 の経過とともに、疲労感が増す（数值が下がる）傾向がみられ、1 回目 (12 分後) の申告に比心゙、 2 回目 (33 分後) の申告值が有意に 低い値となっている（p<0.05）。

表 2 の質問 2 の質問項目の中で、図 5 図 6 に示した項目以外は、 室間の申告值に有意水準 10\%未満の差があるものはなかった。

\section{3 一位加算作業のパフォーマンス}

図 8 に両室における一位加算作業の総計算量を示す。総計算量と は 1 回につき 7 分間に渡る一位加算作業で得られた計算量の総数の ことである。総計算量及び誤答率に条件間の有意な差はみられなか ったが、両室ともに 1 回目の総計算量よりも 2 回目の総計算量の方 が多かった。これは学習効果の影響と考えられる。また、各被験者 の誤答数を総回答数で除した誤答率については、室間及び回数間に 有意な差はみられなかった。なお、室 $\mathrm{A}$ と室 $\mathrm{B}$ の入室順序の違いに よる作業成績に関しても有意な差はみられなかった。

\section{4 作業曲線}

被験者が 7 分間行う一位加算作業の 1 分毎の作業量の時間推移を 表す作業曲線 14) を求めた。各室で 2 回ずつ行われる、計 4 回の一位 加算作業のそれぞれについて、作業母曲線を求め、室 A における結 果を図 9 に、室 B における結果を図 10 に示す。この作業母曲線は、 1 分ごとの作業量の被験者全員の平均值の 7 分にわたる経時変化と して表される。

図 9 をみると、一位加算作業開始時（1 分時）に作業量が多く、 その後、减衰曲線を描いていることがわかる。図 10 に示した、ゴム カーペット設置の無い室 B においても、やはり、図 9 に比べて緩や かではあるが減衰傾向がみられた。

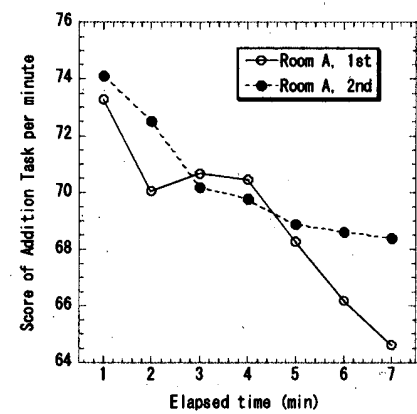

图 9 室Aにおける 1 回目と 2 回目の作業母曲線

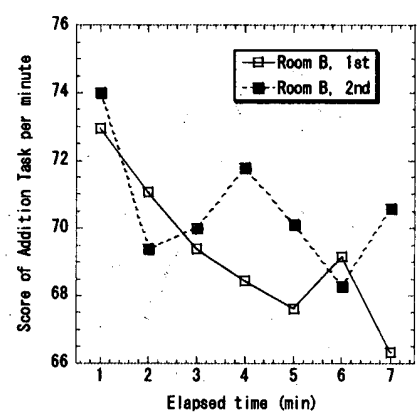

图 10 室Bにおける 1 回目と 2 回目の作業母曲線

\section{4 考察}

図 9、図 10 では、空気污染源（ゴムカーペット）の有無にかかわ らず、作業母曲線は経時减衰していた。クレペリンは作業曲線に関 する研究を発表したとき、このような精神作業に影響を及ぼす心理 的因子として、意思努力、興奮、疲労、慣れ、練習の 5 つを挙げて 
いる ${ }^{8)}$ 。被験者毎の作業曲線をみると、図 9、図 10 のような経時堿 衰傾向は、全ての被験者の作業曲線に見られるわけではなく、経過 時間とともに减衰する傾向を示さない被験者も半数程度いた。中 塚・奥本が被験者の作業曲線について指数関数近似を行なったこと を参考 14）に、本実験の各被験者の室 A における作業曲線に、式(1) に示す一次指数减衰曲線回帰を施した。その結果を表 4 に示す。表 4 には、最小自乗法によって得られた式(1)中の $\mathrm{A}_{2}$ の值の正負の別、 及び、回帰式の相関俰数(R)を載せている。ここで、 $\mathrm{A}_{2}$ の值が負であ ると、減衰傾向を示さないことになる。また表 4 にはケンドールに よる負のトレンド検定を行なった結果（ $\mathrm{p}$ 值）も示してあり、 $\mathrm{p}$ 値の 欄に「NO」と記してあるものは、負のトレンドを示していないもの である。

$$
\begin{gathered}
\text { Score }=A_{1}+A_{2} \times \exp \left(-A_{3} \times t\right) \\
\text { Score : 各分における計算量 } \\
t: \text { 経過時間 [分] }
\end{gathered}
$$

\begin{tabular}{|c|c|c|c|c|c|c|}
\hline \multirow[t]{2}{*}{ 被験者 } & \multicolumn{3}{|c|}{1 回目 } & \multicolumn{3}{|c|}{2 回目 } \\
\hline & $\mathrm{A}_{2}$ * & $\mathrm{R}^{\star *}$ & $p^{* * *}$ & $\mathrm{~A}_{2}$ & R & $\mathrm{p}$ \\
\hline 1 & + & 0.90 & 0.005 & + & 0.77 & 0.119 \\
\hline 2 & + & 0.62 & 0.068 & + & 0.93 & 0.035 \\
\hline 3 & + & 0.81 & 0.015 & + & $<0.01$ & NO \\
\hline 4 & + & $<0.01$ & NO & - & 0.44 & 0.281 \\
\hline 5 & - & $<0.01$ & 0.281 & - & 0.67 & NO \\
\hline 6 & - & 0.20 & No & - & $<0.01$ & 0.119 \\
\hline 7 & + & 0.96 & $<0.001$ & + & 0.66 & 0.5 \\
\hline 8 & + & 0.92 & 0.119 & + & 0.84 & 0.005 \\
\hline 9 & + & 0.92 & 0.005 & + & 0.91 & 0.005 \\
\hline 10 & - & 0.42 & 0.386 & + & 0.75 & 0.119 \\
\hline 11 & + & 0.66 & 0.015 & + & 0.63 & 0.068 \\
\hline 12 & - & $<0.01$ & NO & - & 0.94 & NO \\
\hline 13 & + & 0.62 & 0.068 & - & 0.65 & NO \\
\hline 14 & + & 0.65 & 0.068 & - & $<0.01$ & 0.5 \\
\hline 15 & + & 0.89 & $<0.001$ & - & $<0.01$ & NO \\
\hline 16 & + & 0.69 & $<0.001$ & + & 0.96 & 0.001 \\
\hline 17 & + & 0.98 & 0.035 & + & 0.91 & 0.035 \\
\hline 18 & + & .01 & 0.5 & + & 0.79 & NO \\
\hline
\end{tabular}

表 4 作業曲線への減衰曲線回帰及びケン・ー凡の負トレト・検定結果

\section{* : 回州式 (1)において求められた $A_{2}$ の値（正の值は減衰傾向を示す） ** : 回鱽式 (1) で最小自乗近似を行った際の相関係数} *** : ケハトー-ルのトはド検定における值（NO は負トレドではないことの意）

ここで、室 Aにおける 2 回の作業において、2回とも一次指数减 衰回帰の相関係数 $\mathrm{R}$ が 0.6 以上となる被験者群（グループ II）と、 相関係数が 0.6 未満になる、もしくは減衰を示さず上昇曲線となる 被験者群（グループI）とに被験者をグループ分けし、表 4 におい てグループII を、網掛けで示した。グループ分けの境となる相関係 数 0.6 という数值は任意に決めたが、相関係数が 0.6 以上で、減衰
傾向を示す被験者の作業曲線は、ケンドールの負のトレンド検定に おいても、 p 值が小さくなっており、グループ分けの一応の目安に なっていると考えられる。

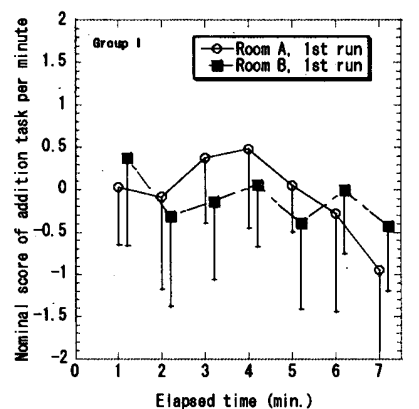

図 $11 ク ゚ ル-フ ゚$ I の両室における 平均作業曲線（1 回目作業時）

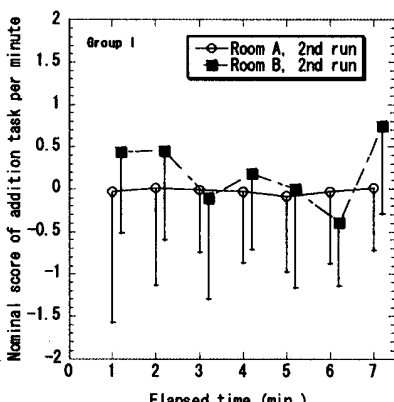

图 $13 ク^{+} ル-フ^{\circ}$ I の両室における 平均作業曲線（2 回目作業時）

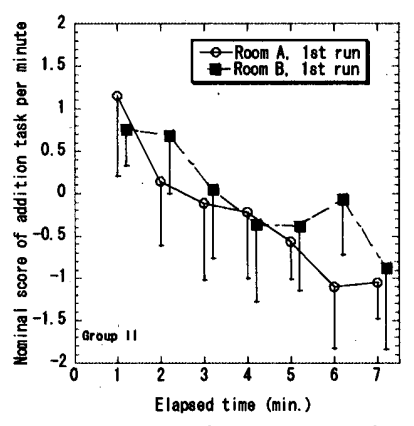

図 $12 ク^{*} \curvearrowleft-フ^{*}$ I の両室の 平均作業曲線（1 回目作業時）

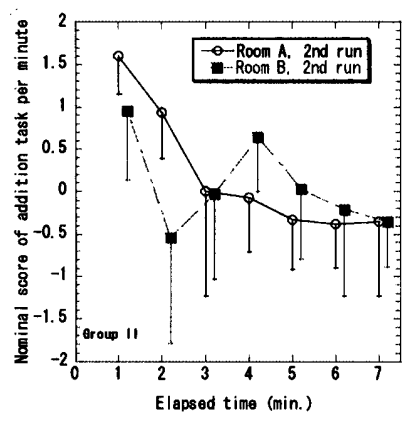

図 14 グループ II の両室の 平均作業曲線（2 回目作業時）

室 $\mathrm{A}$ 及び室 B における、入室後 5〜12 分に行われた、1回目の一 位加算作業時におけるグループ I（10 名）の 1 分あたりの正規化計 算量平均值の作業曲線を図 11 に、グループ II（8名）の正規化計算 量平均值の作業曲線を図 12 に示す。また、室 $\mathrm{A}$ 及び室 $\mathrm{B}$ における、 入室後 25〜32 分に行われた、2 回目の一位加算作業時におけるグル 一プ I の正規化計算量の作業曲線を図 13 に、グループ II の正規化計 算量の作業曲線を図 14 に示す。図 11〜図 14 においてプロット下の バーは標淮偏差の値である。また、正規化計算量とは、室 A で 2 回、 室 B で 2 回、計 4 回にわたる一位加算作業の、被験者毎の平均值、 標準偏差を基に、各被験者について正規化した計算量のことである。 図 13 をみると、グループ I は、特に空気污染物質が設置してある室 $\mathrm{A}$ において、7 分の実施時間における計算量の変動が小さく、一定 の作業量（1 分あたりの作業量）を維持していることがわかる。一 方、グループПでは、室 $\mathrm{A}$ において特に、1 分あたりの計算量の経 時減衰が顕著である（図 14）。

グループ I 及びグループ II の申告する疲労度の平均申告值を図 15 に示す。グループ I では、1 回目 (12 分後) の疲労度申告において、 室 $\mathrm{A}$ と室 $\mathrm{B}$ の疲労度に有意差がみられないが、2回目 (33 分後) の疲労度申告においては、両室に有意な差がみられる(p<0.005)。ま た、グループ I では、室 A において 1 回目の疲労度申告と 2 回目の 疲労度申告に有意な差がみられ( $<<0.05)$ 、滞在時間の経過とともに 疲労度が増大する傾向がみられる。しかし、グループ II では、経過 
時間に伴う疲労度の増大は、どちらの室においてもみられない。グ ループ I とグループ II の疲労度申告值の差は、污染源のある室 A の 2 回目の申告時において有意であり（p<0.05）、グループ I の方が、 グループIより疲れた側の疲労度を申告している。これは、ゴムカ 一ペットから放たれる室内空気污染物質という環境負荷に抗して、 一定の作業量を維持しようとするグループ I の方が、疲労が増大し たためと推察できる。

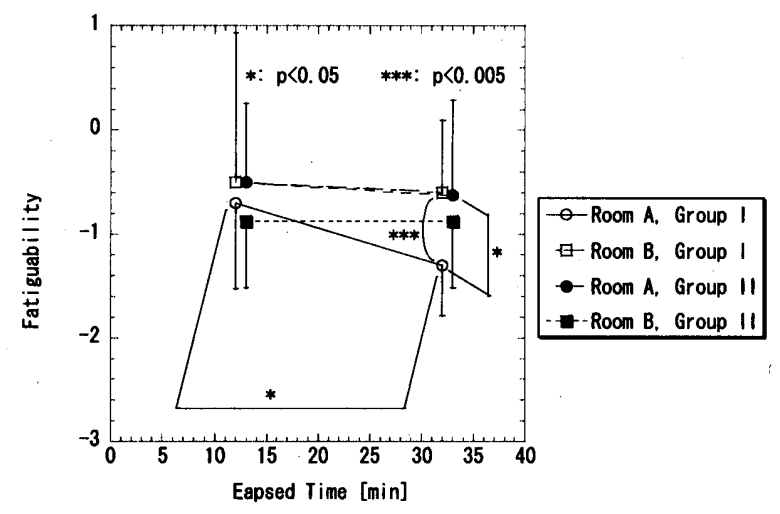

図 15 各グループの疲労度申告の平均値

環境心理学者の Mehrabian は、刺激透過注) の少ない人 (ノンスク リーナー）は、より多くの刺激を感知する傾向をもつため、自分の いる環境を、より負荷の高いものとして体験する、としている 15)。 一方、刺激透過の多い人（スクリーナー）は、環境刺激に対する選 択性が高く、環境刺激を穊いにかけ、効果的に負荷を軽减する傾向 があるとしている。本実験で用いたグループ I 、グループI Iいう グループ分けが、直にノンスクリーナー、スクリーナーに対応する わけではないが、一定作業量を維持するグループの被験者群の方が、 環境刺激をより負荷の高いものとして体験し、疲労感が増す傾向が あったと考えることもできる。その場合、作業曲線の减衰傾向は、 環境負荷を軽减するための刺激透過の度合いを表しているとみるこ とも可能である。

今後は、被験者数を増やすことも含め、被験者のタイプ分けの手 法、基準、被験者のタイプの意義に関して、さらに研究を続ける予 定である。

\section{5. まとめ}

ゴムカーペットを設置した室 $\mathrm{A}$ と、設置しない室 B の両室におい て、被験者を 40 分間滞在させ、 7 分間の一位加算作業を 2 回、空気 環境評価を 3 回、シックビル症候群に関する申告を 2 回行わせた。 その結果、以下の知見が得られた。

1）被験者全員の臭気強度申告平均值は污染源の設置されている室 $\mathrm{A}$ の方が、污染源の設置されていない室 B よりも有意に高く、許容度 申告平均值は室 A において有意に低かった。全被験者の作業後の疲 労度申告平均値は、室 $\mathrm{A}$ と室 $\mathrm{B}$ に有意差はみられなかった。

2）室 A、及び室 B において被験者が行った一位加算作業の総計算 量に有意な差はなかった。

3）各回の一位加算作業の結果から得られる、各被験者の作業曲線パ
ターンが、被験者の心的過程を表しているという仮定をたて、作業 曲線パターンにより被験者をグループ分けした。その結果、作業曲 線パターンが経時減衰傾向を示す被験者（グループII）と、経時減 衰傾向を示さない被験者（グループI）に大別された。空気污染源 が設置されている室 Aにおいて、グループ I は、経過時間にともな う疲労度の増大がグループIIよりも大きかった。空気污染の被験者 の知覚一の影響は、被験者の心理的過程・内的様相の違いによって 異なる感度をもつと考えられる。

注）刺激透過 (stimulus screening) とは、「ある人物が性格的に環境から自分と関 わりの少ない部分をどれだけ監い落とし、それによって環境負荷と自分の覚醒 水帮をいかに効果的に減少するか、ということ」と記述されている ${ }^{15)}$

【謝辞】本研究の一部は、平成 14 年度文部科学省科学研究費基盤研究 A「室 内讟境が知的生産性に与える影響に関する研究（研究代表者 由辺新一）」に よる。

【参考文献】

1) Vernon, H.M., The Influence of hours of work and of ventilation on output in tinplate manufacture., Industrial Fatigue Research Board, Report No.1, H.Majesty's Stationery Office, 1919

2) E.Sundstrom and M.Sundstrom, Work Places, The Psychology of the physical environment in offices and factories, Cambridge University Press, 1986 (邦題 : 仕事 の場の心理学、西村書店、1992)

3) Roesthlisberger, F.J. and Dickson, W.J., Management and the Worker, Harvard University Press, 1949

4）池田央、行動科学の方法、東京大学出版会、1982

5) Oseland, N. (Main author), Environmental Factors Affecting Office Worker Performance: A Review of Evidence, CIBSE Technical Memoranda TM24, 1999

6) Pawel Wargocki, et al., Perceived Air Quality, Sick Building Syndrome(SBS) Symptoms and Productivity in an Office with Two Different Pollution Loads, Indoor Air vol.9, pp165-179,1999

7) Newsham, G.R., Veitch, J.A. and Tiller, D.K., Software Tools to Evaluate Occupant Satisfaction and Performance, Proc. of Healthy Buildings/IAQ'97, Vol.1, pp.207-212, 1997

8）横田象一郎、クレペリン精神作業検查解説、金子書房、1968

9）岩下 剛、木村建一、Experimental Study on the Effect of Loading Factor on Surface Emission Rate of Perceived Air Pollutants、日本建築学会計画系論文報告

集、第 463 号、pp.21-28、1994.9

10) Sollinger, S., Levsen, K., Wunsch, G., Indoor Air Pollution by Organic Emissions from Textile Floor Coverings. Climate Chamber Studies under Dynamic Conditions, Atmospheric Environment Vol. 27B, No.2, pp. 183-192, 1993

11) Fanger, P.O. , Introduction of the Olf and the Decipol Units to Quantify Air Pollution Perceived by Humans Indoors and Outdoors, Energy and Buildings, Vol.12, pp.1-6, 1988

12）岩下㓮、赤坂裕、カーペットから放たれる揮発性有機化合物が在室者の 知覚空気質評価に及ぼす影響に関する研究、空気調和・衛生工学会学術講演会 講演論文集、pp.993-996、1996

13）合原妙美、岩下剛、一般的オフィス空間における執務者の知敩空気質及び Performance の評価方法に関する検討、日本建築学会計画系論文集、第 550 号、pp.107-112、2001.12

14）柏木繁男、内田クレペリンにおける解析的評価法、金子書房、1975 15) Mehrabian, A., Public Places and Private Spaces, Basic Books, Inc, 1976 (邦題 : ヒューマンスペース、川島書店、1981

（2003年 2 月 10 日原稿受理，2003年 7 月 2 日採用決定） 